8-23-2011

\title{
The Internationalization Of Indian SMEs In B-to-B Markets
}

\author{
Rajshekar G. Javalgi \\ Cleveland State University, r.javalgi@csuohio.edu \\ Patricia R. Todd \\ Western Kentucky University, patricia.todd@wku.edu \\ Elad Granot \\ Cleveland State University, e.granot@csuohio.edu
}

Follow this and additional works at: https://engagedscholarship.csuohio.edu/bus_facpub

Part of the Entrepreneurial and Small Business Operations Commons, and the International Business

Commons

How does access to this work benefit you? Let us know!

\section{Publisher's Statement}

This is the Author Accepted Manuscript of an article originally published in Journal of Business \& Industrial Marketing, 08-23-2011, http://dx.doi.org/10.1108/08858621111162343

\section{Original Published Citation}

Javalgi, R.G., Todd, P., \& Granot, E. (2011). The internationalization of Indian SMEs in B-to-B markets. Journal of Business \& Industrial Marketing, 26(7), 542-548. doi: 10.1108/08858621111162343

This Article is brought to you for free and open access by the Monte Ahuja College of Business at EngagedScholarship@CSU. It has been accepted for inclusion in Business Faculty Publications by an authorized administrator of EngagedScholarship@CSU. For more information, please contact library.es@csuohio.edu. 


\title{
The internationalization of Indian SMEs in B-to-B markets
}

\author{
Rajshekhar (Raj) G. Favalgi \\ Department of Marketing, Cleveland State University, Cleveland, Ohio, USA \\ Patricia Todd \\ Western Kentucky University, Bowling Green, Kentucky, USA, and \\ Elad Granot \\ Department of Marketing, Cleveland State University, Cleveland, Ohio, USA
}

\begin{abstract}
Purpose - The study aims to examine the effect of market orientation on the international performance of Indian SMEs in the business-to-business market; assess the potential moderating effect of environmental uncertainty, along with market orientation, on SMEs' performance; and discuss implications to guide SME owners/managers in their efforts to successfully expand internationally in turbulent markets.

Design/methodology/approach - Surveys were sent to a random cross-sectional industry sample of SMEs located in India. The data consisted of 150 responses.

Findings - Market orientation and international orientation are positively related to export performance and the relationship between the market orientation and international performance of Indian SMEs is moderated by market turbulence.

Research limitations/implications - The data were collected at a single point in time, and therefore do not allow the determination of cause and effect or the impact of changes over time. Data were collected with a reliance on self-reports for all of the research variables.

Practical implications - The positive relationship between market orientation, international orientation, and the degree of internationalization of the firm would suggest that the upper management of Indian SMEs should place a priority on promoting behaviors consistent with a positive international orientation, especially in turbulent markets.

Originality/value - Studies focused on market orientation have been done primarily in the context of advanced economies. The significant economic contribution of SMEs is well understood, but their business practices in emerging economies have not been studied extensively. This study extends the literature concerning factors that impact business success in an important emerging market such as India.
\end{abstract}

Keywords Market orientation, Small to medium-sized enterprises, Business to business marketing, International business, India

Paper type Research paper

\section{Introduction}

Small to medium-size enterprises (SMEs) involved in business-to-business transactions play an important role in the global marketplace. They make a significant contribution to international trade due to their entrepreneurial spirit, innovation, and the creation of resilient economic systems. Technological advances and the opening of markets create challenges for SMEs. SMEs in emerging markets rely on more labor-intensive production processes than large enterprises, boosting employment and leading to more equitable income distribution (Luetkenhorst, 2004). They also provide livelihood opportunities through simple, value adding processing activities in knowledge-based economies, supporting the growth of systemic productive capacities. Indian SMEs, in reaction to governmental changes in trade practices, have to re-think their business strategy in order to expand into new markets and face new competition. Studies focused on market orientation, a strategy that can be used to achieve a competitive advantage, have been done primarily in the context of advanced economies (Kohli and Jaworski, 1990). While the significant economic contribution of SMEs is well understood, their business practices in emerging economies have not been extensively studied.

The purpose of this research is to evaluate the impact of market orientation on the performance of SMEs in the emerging market of India, specifically in the business-tobusiness marketplace, under environmental uncertainty. More specifically, the study attempts:

- to examine the effect of market orientation on the international performance of Indian SMEs;

- to assess the potential moderating effect of environmental uncertainly, along with market orientation, on the SMES performance; and

- to discuss implications to guide SMEs owners/managers in their effort to successfully expand internationally in turbulent markets characterized by competitive and technological intensity.

The paper is structured as follows: section 2 provides a foundation establishing the importance of B-to-B firms in India. The next section consists of a brief literature review of internationalization of Indian SMEs in the global economy and introduces the concept of market orientation. Section 4 
focuses on the development of hypothesis. The research design, presentation of the results and analysis follow. Finally, the paper concludes with implications and limitations of the study.

\section{The importance of B-to-B firms in India}

Growth estimates continue to show India as one of the fastest growing economies in the world[1]. Small business in India is the second largest employer of human resources, after agriculture[2]. The private sector leads this growth, with initiatives focused on infrastructure development and the advancement of manufacturing capabilities. Considerable growth is occurring in specific areas such as aerospace, specialized materials, information and communication technologies, electronics and flexible manufacturing systems[2]. The production of equipment to support the growth of nuclear reactors in India is expected to exceed $\$ 40$ bn by 2020 [1]. Even though large Indian multinational corporations are focused in these areas, smaller businesses provide the foundation for support. For example, 23 percent of all manufacturing enterprises in India have fewer than ten employees[3]. International business-to-business (B-to-B) markets are increasingly attractive for small and mediumsized companies. Although small and medium-sized exporters may not be able to compete on price with global and large exporters, their flexibility and entrepreneurial operating style allows them to provide more customized, innovative services (Lages et al., 2008).

There are many reasons for the growth of SMEs in India. Some of these include the increase in the demand for products exported from India, the availability of manpower not being an issue, and the government purchasing exclusively from Indian SMEs[2]. Several reforms aimed at promoting the growth of small businesses have been enacted. These include providing training facilities, rent-to-own contracts for heavy equipment, bonuses for starting small businesses in under-developed areas, tax incentives for small businesses, and support for marketing in domestic and international markets [2]. It is clear that SMEs play an important role in the economic stability of India, but an understanding of their managerial strategy is key to understanding their growth and success.

\section{Literature review and hypothesis development}

\subsection{Hypothesis related to market orientation and} international performance

The concept of market orientation is based on the notion of the marketing concept, which holds that the success of the organization lies in meeting and satisfying the needs of customers. It is assumed that a firm can achieve sustainable competitive advantage by creating superior value for customers (Narver and Slater, 1990; Castro et al., 2005). Narver and Slater (1990, p. 21) define market orientation as "the organization culture that most effectively and efficiently creates the necessary behaviors for the creation of superior value for buyers and, thus, continuous superior performance for the business". According to their conceptualization, it can be seen as a construct consisting of three behavioral components:

1 customer orientation;

2 competitor orientation; and

3 inter-functional coordination.
This has been further modified to suit the context of small firms (Pelham, 1997; Appiah-Adu and Singh, 1998). Market orientation and customer orientation are connected, as they both focus on achieving competitive advantage and positive firm performance, even though there is some disagreement among the scholars in terms of domain and hierarchy (Ruokonen et al., 2008). Market orientation provides a means of assessing the overall customer and marketing focus of an organization.

Over the past two decades, many conceptual and empirical papers on the various aspects of market orientation have been published in various disciplines, including international management and international marketing. As a whole, previous research highlights the importance of the relationship between market orientation and business performance. Studies focusing on Western companies suggest a strong, positive relationship between market orientation and business performance (Kumar et al., 1998; Jaworski and Kohli, 1993; Narver and Slater, 1990; Deshpande et al., 1993; Deshpande and Farley, 1996). However, mixed findings were reported in non-US studies. For instance, Diamantopoulos and Hart (1993), focusing on UK companies, identified a weak association between market orientation and firm performance. Using samples from Saudi Arabian banks, Bhurian (1998) examined the relationship between market orientation and performance, and found no support for the relationship. However, Deng and Dart (1994), in a study of 248 Canadian companies, found significant support for market orientation and performance.

Given the inconsistency of findings among the non-US studies, there is a need to assess the role of market orientation in non-Western companies. In light of this, recent studies have called for more research to test empirically the relationship between market orientation and business performance (Deshpande and Farley, 1996, 2000). Market orientation, as a resource, is rare in emerging markets such as India and China, since in emerging economies the focus seems to be more technical and production-based rather than marketoriented (Deshpande and Farley, 2000). Therefore, to succeed in the highly competitive global environment, market orientation becomes important for Indian SMEs. Based on the above discussion, we propose the following hypothesis:

H1. Market orientation is positively related to international performance of Indian SMEs.

\subsection{Hypothesis related to managers' international orientation and international performance}

Managerial commitment to internationalization is likely to have a particularly strong impact on the export behavior and success of Indian SMEs. This is primarily attributed to the existence of considerable differences in market characteristics between India and the developed economies such as the USA. "Managers' international orientation" refers to managers' attitudes towards international affairs and their flexibility to adjust to working with different cultures (Nummela et al., 2004). It is demonstrated through managers' commitment to international markets, the presence of international business vision and proactiveness, as well as an overall focus on a customer orientation (Knight, 1997; Moen, 2002). According to Knight (1997), companies that are involved in a rapid internationalization process tend to be more internationally 
oriented than those that are not. Researchers have found that internationally oriented managers can be described as having a positive attitude towards exporting and have experience in dealing with foreign markets (Dichtl et al., 1990, Nummela et al., 2004). Studies have linked international orientation with the international performance of the firm (Knight, 1997, 2001).

H2. Managers' international orientation is positively related to international performance of Indian SMEs.

\subsection{Moderating effect of market turbulence}

Market turbulence refers to the variability and unpredictability of customer preferences and expectations (Gatignon and Xuereb, 1997; Jaworski and Kohli, 1993). Demand uncertainty requires firms to adapt their product offerings and strategies to the changing needs of customers. As innovators, firms must usually make their investment decisions, such as plant capacity, knowing that future demand is uncertain (Wernerfelt and Karnani, 1987). Kohli and Jaworski (1990) and Slater and Narver (1994) associate market turbulence with the changes in the composition of customers and their preferences. For Hult et al. (2004), market turbulence reflects rapidly changing buyer preferences, wide-ranging needs and wants, ongoing buyer entry and exit from the marketplace and constant emphasis on offering new products. In this investigation, the market turbulence concept also tries to capture the dynamism in the customer base and needs, but two additional components are introduced in its definition:

1 the rate of change of the firm's competitors; and

2 the market uncertainty.

However, environmental factors as a moderating effect of the relationship between market orientation and organizational performance are not positive and significant (Jaworski and Kohli, 1993; Wood et al., 2000). The anticipated relation from market orientation and international performance are both stronger under market turbulence for SMEs in India, leading to the following hypothesis:

H3. The relationship between market orientation and international performance of Indian SMEs is moderated by market turbulence.

\subsection{Moderating effect of competitive intensity}

Competitive intensity is defined as the degree of competition that a firm faces (Zhao and Cavusgil, 2006). Competitive intensity is the scope to which external environments are characterized by extreme competition (Hill and Matusik, 1998). Competitive intensity has been involved with lower performances (Hill and Matusik, 1998) that lead to rapid response to changes in a firm's competitive environment (Zahra and Garvis, 2000). In practice, expanded risk-taking, powerful proactiveness, and intense focus on innovation can be risky when competitive conditions become more demanding (Miller and Friesen, 1983). Innovation outcomes lead to fast dispersion over the population of competitors (Levinthal and March, 1993). Furthermore, competitive intensity commonly decreases available resources for innovation outcomes (Miller and Friesen, 1983; Zahra and Garvis, 2000), and pursuing such high-risk and high-cost innovations would considerably damage the viability of organizational (Zahra and Bogner, 2000).
Organizations reacting to existing trends and demands through adjusting or extending current products, services, and markets (i.e. innovation outcomes) are likely to improve their performance in competitive environments (Lumpkin and Dess, 2001). They pursue innovation outcomes to better cater to existing customers and build customer loyalty without substantial costs involved with innovation outcomes. Therefore, innovative outcomes improve advertising and enhance tailoring of existing products and services (Miller, 1987). These organizations try to charge a premium and capture additional market share (Zahra and Bogner, 2000). Furthermore, innovation outcomes with competitive intensity are likely to increase a firm's export performance. Therefore, we posit the hypothesis below:

H4. Competitive intensity will positively moderate the relationship between market orientation and international performance of Indian SMEs.

\section{Research design}

The objective of this study was to investigate the factors that impact the international growth of SMEs in India, adding to the sparse amount of literature currently available. The research design consisted of a pretest of the survey instrument, after consulting with five business owners in Mumbai who provided input on the wording of the survey. Subsequently the survey was sent to ten business owners for traditional pre-testing. The sample is comprised of privately owned SMEs, randomly selected, representing a cross-section of industries in the B-to-B sector. Survey respondents were pre-qualified by telephone and e-mail to verify that:

- they had fewer than 500 employees;

- they were involved in international business; and

- the respondents were an owner, CEO, or a key international management executive.

A total of 150 responses were received. Smaller SMEs (i.e. 25-49 employees) were well represented, comprising nearly 50 percent of the respondents, and the remaining were distributed as follows:

- 19 percent reported between 50 and 100 employees;

- nearly 20 percent reported between 100 and 250 employees; and

- the remainder reported 250-500 employees.

Reported annual sales revenue indicated that:

- 31 percent earn less than $\$ 100,000$;

- 39.5 percent earn $\$ 100,000-\$ 499,000$;

- 7 percent earn $\$ 500,000-\$ 999,000$;

- 6.5 percent earn $\$ 1 \mathrm{~m}-\$ 4.9 \mathrm{~m}$; and

- 10.4 percent earn over $\$ 5 \mathrm{~m}$.

\section{Reliability measures}

The survey instrument developed for this research study utilizes existing scale items which have all been empirically tested in prior research and reported as possessing strong reliability and validity (see Table I).

Different measures of market orientation have been discussed in the literature (Narver and Slater, 1990; Kohli et al., 1993; Deshpande et al., 1993; Deshpande and Farley, 1999). In this article, the scale of Deshpande and Farley (1999) was used as it had the advantage of having relatively 
Table I Sample items, source, and reliability of the constructs

\begin{tabular}{|c|c|c|c|}
\hline Scale (Cronbach's $\alpha$ ) & $\begin{array}{l}\text { Number of } \\
\text { items }\end{array}$ & Sample items & Prior research support \\
\hline $\begin{array}{l}\text { Market orientation } \\
\text { (Cronbach's } \alpha=0.90)\end{array}$ & 10 & $\begin{array}{l}\text { We measure customer satisfaction } \\
\text { We constantly monitor our level of commitment and orientation to serving } \\
\text { customer needs } \\
\text { Our strategy for competitive advantage is based on our understanding of } \\
\text { customers' needs }\end{array}$ & Deshpande and Farley (1996) \\
\hline $\begin{array}{l}\text { Competitive intensity } \\
\text { (Cronbach's } \alpha=0.72 \text { ) }\end{array}$ & 4 & $\begin{array}{l}\text { Competition in our industry is cutthroat } \\
\text { There are many "promotion wars" in our industry }\end{array}$ & Jaworski and Kohli (1993) \\
\hline $\begin{array}{l}\text { Market turbulence } \\
\text { (Cronbach's } \alpha=0.71 \text { ) }\end{array}$ & 4 & $\begin{array}{l}\text { Our customers tend to look for new products all the time } \\
\text { We are witnessing demand for our products and services }\end{array}$ & Jaworski and Kohli (1993) \\
\hline $\begin{array}{l}\text { International orientation/ } \\
\text { global mindset (Cronbach's } \\
\alpha=0.91 \text { ) }\end{array}$ & 7 & $\begin{array}{l}\text { The company's management uses a lot of time in planning international } \\
\text { operations } \\
\text { Commitment to internationalization is measured according to statements } \\
\text { referring to the top managers concrete behavior related to international } \\
\text { activities } \\
\text { The growth we are aiming at can mainly be achieved through international } \\
\text { operations }\end{array}$ & Nummela et al. (2004) \\
\hline International performance & 1 & Percentage of foreign sales to total sales & $\begin{array}{l}\text { Lu and Beamish (2001), Kumar } \\
\text { and Singh (2008) }\end{array}$ \\
\hline
\end{tabular}

few items (i.e. ten), thus keeping the length of the questionnaire to a manageable level. All the items were measured using a scale ranging from 1 (strongly disagree) to 7 (strongly agree). When exploratory factor analysis was conducted on the ten items, all the items loaded very highly (between 0.60 and 0.89), except for two items that showed a loading below 0.45 . These items were deleted from the analysis. As shown in Table I, the reliability score on the eight items was very high (0.90) and met the required criterion of 0.70 .

The market turbulence and competitive intensity scales were based on Jaworski and Kohli (1993), and each construct was made of four items. Each item was measured using a scale ranging from 1 to 7 , where 1 indicates that the respondent strongly disagrees with the statement and 7 indicates strong agreement with the statement. The scales measurement properties have been empirically found to show unidimensionality (Jaworski and Kohli, 1993; Rose and Shoham, 2002). As shown in Table I, the reliability scores for market turbulence (0.71) and competitive intensity (0.72) met the recommended criterion of 0.70 (Nunnally, 1978).

International orientation was measured using the scale measuring attitude towards internationalization used by Nummela et al. (2004). The scale consists of seven Likertscale items ( $1=$ strongly disagree, $5=$ strongly agree) that can be combined into a single measure. The questions focus on the manager's perception of the importance of internationalization. Exploratory factor analysis produced one factor (Nummela et al., 2004) and the reliability score was 0.91 (see Table I).

International performance is measured as a ratio of export sales to total sales, referred to as the internationalization ratio (Arora et al., 2004; Ogunmokun and Ng, 2004; Chrisman and Leslie, 1989; Yeoh, 2004). Researchers have used the export ratio as a measure of international performance (Buckley, 1997; Francis and Collins-Dodd, 2000; Lu and Beamish,
2001). The higher the percentage of foreign sales to total sales, the greater the degree of internationalization (Wolff and Pett, 2000). Control variables consisted of the firm size (i.e. number of employees) and the age of the firm. In India, English is the dominant language used by businesses and the government of India; therefore, the survey was prepared in English.

\section{Results}

All the hypotheses were tested by multiple regression analysis. This technique is commonly used to analyze the relationships between a dependent variable and independent variables. The results of the regression are shown in Table II.

The dependent variable used was international performance. The $R^{2}$ value (0.29) and $F$-statistic (6.67) show that the regression model fits well (see Table II),

Table II Regression results with international performance as the dependent variable

\begin{tabular}{lc}
\hline Variable & Coefficient \\
\hline Market orientation (MO) & $0.57^{*}$ \\
International orientation (IO) & $0.32^{* *}$ \\
Market turbulence (MT) & $0.41^{*}$ \\
Competitive intensity (CI) & 0.24 \\
MO $\times$ MT & $0.49^{*}$ \\
MO $\times \mathrm{Cl}$ & 0.07 \\
Control variables & \\
Number of employees & 0.02 \\
Years in international business & $0.34^{*}$ \\
Adjusted $R^{2}$ & 0.29 \\
F statistic & $6.67^{* *}$ \\
Notes: ${ }^{*} p<0.05 ; * *<0.01$ & \\
\hline
\end{tabular}


explaining the relationship between independent variables and dependent variables. As can be seen in Table II, the variable market orientation was significant $(\beta=0.57, p<0.05)$, confirming $H 1$ that there is a positive relation between market orientation and international performance. There is also support for $\mathrm{H} 2$ as the variable international orientation was also significant $(\beta=0.32, p<0.01)$, suggesting a positive relationship between international orientation and international performance. The interaction between market orientation and market turbulence was significant $(\beta=0.49$, $p<0.05)$, supporting H3. This suggests that market turbulence moderates the relationship between market orientation and international performance. However, support for $\mathrm{H} 4$ was not found, as the interaction between market orientation and competitive intensity was not statistically significant $(\beta=0.07, p<0.30)$.

Of the two control variables, the size of the company (as measured by the number of employees) was not significant, suggesting no impact of the size of the company on a firm's international experience. However, the number of years in international business was significant. This shows that firms that have been established for some time have a competitive advantage in the marketplace, in our case in business-tobusiness markets.

\section{Discussion and implications}

One of the managerial goals of any firm is to establish a competitive advantage, allowing management to attain financial goals. Due to the increase in domestic competitive intensity created by government reform, Indian SMEs must find ways in which to develop strategies and promote performance allowing international expansion. The results of this research identify several key potential performance enhancing factors. The positive relationship between market orientation and the degree of internationalization of the firm would suggest that the upper management of SMEs should prioritize promoting behaviors consistent with a positive international orientation, especially in turbulent markets.

Another behavioral factor to focus on is the development of an international vision, encouraging employees to see the world as one big marketplace. As mentioned, a small firm is an extension of the management's orientation with regard to internationalization and entrepreneurial orientation and the attitudes and commitment of top management have been shown to impact a small firm's ability to enter global markets (Knight, 2001; Kuivalainen et al., 2004). The importance of top managers communicating their commitment to internationalization, as measured through their concrete behaviors, also aids in building a positive attitude towards internationalization, which has a positive relationship to the degree of internationalization.

The importance of relationships supported by the analysis of the data also can aid in obtaining, developing and retaining employees who exhibit behavioral characteristics consistent with a positive attitude towards internationalization. Training programs aimed at providing an understanding of the importance of acting in a proactive manner, embracing risk and innovation, along with developing an international view of the business would be one way to practically apply the results of this research.

The presence or absence of characteristics associated with market orientation and attitude towards internationalization would guide venture capitalists and public policy makers in terms of where to direct resources when considering SMEs and their potential growth through international expansion. This becomes more important as the population of SMEs increases. From an organizational perspective, upper management could use the information gained from this study as additional proof that the environmental forces should be monitored.

\section{Theoretical and research limitations}

The purpose of this research was two-fold. First, the goal was to extend the literature addressing the relationships surrounding the internationalization of small and mediumsized enterprises (SMEs) in India. Specifically, we wanted to improve the understanding of how market orientation and international orientation influence the firm's degree of internationalization, and the moderating effect of environmental turbulence. The links between international orientation, market orientation, and the degree of internationalization and the impact of environmental turbulence were all supported by the data. Second, armed with the empirical data, this research provides a foundation or framework through the identification of behavioral characteristics that positively impact international growth and give a small or medium-sized firm in an emerging market a way to develop competitive advantage in a highly dynamic business environment.

This research does not take into account changes over time as the data were collected at a single point in time. It does not allow of the determination of cause and effect or the impact of changes over time (Zikmund, 2003). A longitudinal study would allow the firm to be studied over time and would give a clearer picture of the failure rates and the reasons for success or failure. Also, the sample represented SMEs from a restricted region in India, which may constrict the ability to generalize the findings to other regions or countries. The reasoning behind choosing the area utilized in this study was to keep extraneous environmental factors to a minimum.

Another limitation is that the data was collected with a reliance on self-reports for all of the research variables. Of particular concern is the reporting of financial information. An objective response was used in this study. There is no way to check the accuracy of the data, as no secondary sources are available. Therefore the construct validity of the measures could not be tested directly.

Third, the dependent variable consisting of the degree of internationalization, measured as foreign sales as a percentage of total sales, does not give any quantitative indication of the firm's growth or profitability. There is also a great deal of disagreement in the literature on the best way to measure firm performance. The difficulty inherent in obtaining performance data, especially from SMEs, remains a challenge.

SMEs are making a larger and larger impact on the economy. The environment in which SMEs must do business requires that they undergo international expansion to grow. In some cases, they need to expand to take advantage of new market opportunities. In others, they have to follow large customers to maintain an important supplier relationship. In either case, in order to enter international markets successfully, upper level management or owners need to develop strategies that will promote the behaviors that aid in successful expansion. 
The results of this study support the importance of the attitude of upper management and its impact on internationalization of the firm. The impact of management's attitude has been studied intensely in domestic firms, but relatively less research is focused on the management of SMEs in terms of internationalization, establishing the link with market orientation. Market orientation can be high, but if management is not interested in the international market, the degree of internationalization will be lower. Owners and top managers of SMEs who implement programs to develop a positive attitude towards internationalization among employees and demonstrate the importance of thinking outside the domestic market will improve the probability of success and create a competitive advantage.

\section{Notes}

1 See http://economictimes.indiatimes.com/news/economy/ indicators/manufacturing-helps-GDP-grow-74.in-Y10-ar ticleshow/5996613 (accessed 23 August 2010).

2 See http://businessmapsofindia.com/india-business/ small-business.html (accessed 18 August 2010).

3 See www.dare.co.in/graphs-statistics/infrastructure/whatpercentage-of-the-total-are-small-business.htm (accessed 18 August 2010).

\section{References}

Appiah-Adu, K. and Singh, S. (1998), "Customer orientation and performance: a study of SMEs", Management Decision, Vol. 36 Nos 5/6, pp. 385-95.

Arora, A., Jaju, A., Kefalas, A.G. and Perenich, T. (2004), "An exploratory analysis of global managerial mindsets: a case of US textile and apparel industry", Fournal of International Management, Vol. 10, pp. 393-411.

Bhurian, S.N. (1998), "An empirical examination of market orientation in Saudi Arabian manufacturing companies", Fournal of Business Research, Vol. 43 No. 1, pp. 13-25.

Buckley, P.J. (1997), "International technology transfer by small and medium-sized enterprises", Small Business Economics, Vol. 9, pp. 67-78.

Castro, C.B., Amario, E.M. and DelRio, M.E.S. (2005), "Consequences of market orientation for customers and employees”, European fournal of Marketing, Vol. 39 Nos 5/6, pp. 646-75.

Chrisman, J.J. and Leslie, J. (1989), "Strategic, administrative, and operating problems: the impact of outsiders on small firm performance", Entrepreneurship: Theory and Practice, Vol. 13 No. 3, pp. 37-51.

Deng, S. and Dart, J. (1994), "Measuring market orientation: a multi-factor, multi-item approach", Fournal of Marketing Management, Vol. 10 No. 8, pp. 725-42.

Deshpande, R. and Farley, J.U. (1996), "Understanding market orientation: a prospectively designed meta-analysis of the market orientation scales”, Working Paper No. 96-125, Marketing Science Institute, Cambridge, MA.

Deshpande, R. and Farley, J.U. (1999), "Understanding market orientation: a prospectively designed meta-analysis of three market orientation scales", in Deshpande, R. (Ed.), Developing a Market Orientation, Sage Publications, London, pp. 217-37.
Deshpande, R. and Farley, J.U. (2000), "Market-focused organizational transformation in China", fournal of Global Marketing, Vol. 14 Nos 1/2, pp. 7-36.

Deshpande, R., Farley, J.U. and Webster, F.E. (1993), "Corporate culture, customer orientation, and innovativeness in Japanese firms: a quadrant analysis", Fournal of Marketing, Vol. 57 No. 1, pp. 23-37.

Diamantopoulos, A. and Hart, S.J. (1993), "Linking market orientation and company performance: preliminary evidence on Kohli and Jaworski framework", Fournal of Strategic Management, Vol. 1 No. 2, pp. 93-121.

Dichtl, E., Koeglmayr, H. and Mueller, S. (1990), "International orientation as a precondition for export success", fournal of International Business Studies, Vol. First Quarter, pp. 23-40.

Francis, J. and Collins-Dodd, J. (2000), "The impact of firm's export orientation on the export performance of high-tech small and medium sized enterprises", fournal of International Marketing, Vol. 8 No. 3, pp. 84-103.

Gatignon, H. and Xuereb, J. (1997), "Strategic orientation of the firm and new product performance", Fournal of Marketing Research, Vol. 34 No. 1, pp. 77-90.

Hill, C.W. and Matusik, S.F. (1998), "The utilization of contingent work, knowledge creation, and competitive advantage", Academy of Management Review, Vol. 23 No. 4, pp. 680-97.

Hult, G.T.M., Hurley, R.F. and Knight, G. (2004), "Innovativeness: its antecedents and impact on business performance”, Industrial Marketing Management, Vol. 33, pp. 429-38.

Jaworski, B.J. and Kohli, A.J. (1993), "Market orientation: antecedents and consequences", fournal of Marketing, Vol. 57 No. 3, pp. 53-81.

Knight, G. (1997), "Cross-cultural reliability and validity of a scale to measure firm entrepreneurial orientation", fournal of Business Venturing, Vol. 12, pp. 213-25.

Knight, G. (2001), "Entrepreneurship and strategy in the international SME", fournal of International Management, Vol. 7, pp. 155-71.

Kohli, A.K. and Jaworski, B.J. (1990), "Market orientation: the construct, research propositions, and managerial implications", fournal of Marketing, Vol. 54, April, pp. 1-18.

Kohli, A.K., Jaworski, B.J. and Kumar, A. (1993), "MARKOR: a measure of market orientation", fournal of Marketing Research, Vol. 30 No. 4, pp. 467-77.

Kuivalainen, O., Sundqvist, S., Puumalainen, K. and Cadogan, J.W. (2004), "The effect of environmental turbulence and leader characteristics on international performance: are knowledge based firms different?", Canadian fournal of Administrative Sciences, Vol. 21 No. 1, pp. 35-50.

Kumar, V. and Singh, N. (2008), "Internationalization and performance of Indian pharmaceutical firms", Thunderbird International Business Review, Vol. 50 No. 5, pp. 321-30.

Kumar, K., Subramanian, R. and Yauger, C. (1998), "Examining the market orientation-performance relationship: a context-specific study", Fournal of Management, Vol. 24 No. 2, pp. 201-33.

Lages, L.F., Abrantes, J.L. and Lages, C.R. (2008), "The STRATADAPT scale: a measure of marketing strategy adaptations to international business markets", International Marketing Review, Vol. 25 No. 5, pp. 584-600. 
Levinthal, D.A. and March, J.G. (1993), "The myopia of learning", Strategic Management fournal, Vol. 14, Winter, pp. 95-112.

Lu, J.W. and Beamish, P.W. (2001), "The internationalization and performance of SMEs", Strategic Management fournal, Vol. 22, pp. 565-86.

Luetkenhorst, W. (2004), "Corporate social responsibility and the development agenda", Intereconomics, Vol. 39 No. 3, pp. 157-66.

Lumpkin, G.T. and Dess, G.G. (2001), "Linking dimensions of entrepreneurial orientation to firm performance: the moderating role of environment and industry life cycle", Fournal of Business Venturing, Vol. 16, pp. 429-51.

Miller, D. (1987), "The structure and environmental correlates of business strategy", Strategic Management fournal, Vol. 8, pp. 55-76.

Miller, D. and Friesen, P.H. (1983), "Strategy-making and environment: the third link", Strategic Management fournal, Vol. 4, pp. 221-35.

Moen, O. (2002), "The born globals: a new generation of small European exporters", International Marketing Review, Vol. 19 Nos 2/3, pp. 156-76.

Narver, J.C. and Slater, S. (1990), "The effect of market orientation on business profitability", fournal of Marketing, Vol. 54 No. 4, pp. 20-35.

Nummela, N., Saarenketo, S. and Puumalainen, K. (2004), "Attitude towards internationalization - a prerequisite for successful internationalization?", Canadian fournal of Administrative Sciences, Vol. 21 No. 1, pp. 51-64.

Nunnally, J.C. (1978), Psychometric Theory, 2nd ed., McGraw-Hill, New York, NY.

Ogunmokun, G. and Ng, S. (2004), "Factors influencing export performance in international marketing: a study of Australian firms", International fournal of Management, Vol. 21 No. 2, pp. 172-85.

Pelham, A.M. (1997), "Mediating influences on the relationship between market orientation and profitability in small industrial manufacturing firms", fournal of Marketing Theory and Practice, Vol. 15 No. 3, pp. 55-77.

Rose, G.M. and Shoham, A. (2002), "Export performance and market orientation: establishing an empirical link", Fournal of Business Research, Vol. 55 No. 3, pp. 217-25.
Ruokonen, M., Nummela, N., Puulalainen, K. and Saarenketo, S. (2008), "Market orientation and internationalization in small software firms", European Fournal of Marketing, Vol. 42 Nos 11/12, pp. 1294-315.

Slater, S.F. and Narver, J.C. (1994), "Does competitive environment moderate the market orientation-performance relationship?", Fournal of Marketing, Vol. 58 No. 1, pp. 46-55.

Wernerfelt, B. and Karnani, A. (1987), "Competitive strategy under uncertainty", Strategic Management fournal, Vol. 8 No. 2, pp. 187-94.

Wolff, J.A. and Pett, T.L. (2000), "Internationalization of small firms: an examination of export competitive patterns, firm size, and export performance", fournal of Small Business Management, April, April, pp. 34-47.

Wood, V.R., Bhuian, S. and Kiecker, P. (2000), "Market orientation and organizational performance in not-for-profit hospitals", Fournal of Business Research, Vol. 48 No. 3, pp. 213-26.

Yeoh, P. (2004), "International learning: antecedents and performance implications among newly internationalizing companies in an exporting context", International Marketing Review, Vol. 21 Nos 4/5, pp. 511-35.

Zahra, S.A. and Bogner, W.C. (2000), "Technology strategy and software new ventures' performance: exploring the moderating effect of the competitive environment", fournal of Business Venturing, Vol. 15 No. 2, pp. 135-73.

Zahra, S.A. and Garvis, D.M. (2000), "International corporate entrepreneurship and firm performance: the moderating effect of international environmental hostility", Fournal of Business Venturing, Vol. 15, pp. 469-92.

Zhao, Y. and Cavusgil, T. (2006), "The effect of supplier's market orientation on manufacturer's trust", Industrial Marketing Management, Vol. 35 No. 4, pp. 405-14.

Zikmund, W.G. (2003), Exploring Market Research, 8th ed., Thompson Southwestern, Cincinnati, OH.

\section{Corresponding author}

Elad Granot can be contacted at: e.granot@csuohio.edu 